\title{
Immunohistochemical Analysis of P-gp, LC3-II, and Cathepsin-D Associated with Histological Changes in Fish Liver: from the Impacted Environment to Clean Water
}

\author{
Anderson Kelvin Saraiva Macêdo ${ }^{1}$ \\ https://orcid.org/0000-0002-0404-1681 \\ Danúbia Domingos Epifânio ${ }^{1}$ \\ https://orcid.org/0000-0002-6018-3174

\section{Rubianne Araújo Carvalho ${ }^{1}$ \\ https://orcid.org/0000-0002-4284-2930}

\author{
Rosy lara Maciel de Azambuja Ribeiro² \\ https://orcid.org/0000-0002-7374-4743 \\ Hélio Batista dos Santos ${ }^{1}$ \\ https://orcid.org/0000-0001-6813-8522
}

\author{
Ralph Gruppi Thomé ${ }^{1 *}$ \\ https://orcid.org/0000-0002-1779-5036
}

${ }^{1}$ Federal University of São João Del Rei, Campus Centro Oeste, Tissue Processing Laboratory - LAPROTEC,

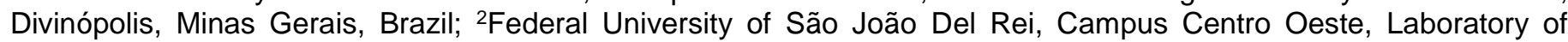
Experimental Pathology - LAPATEX, Divinópolis, Minas Gerais, Brazil.

Received: 2019.12.02; Accepted: 2020.04.21.

*Correspondence: ralph@ufsj.edu.br; Tel.: +55-37-36904450

\section{HIGHLIGHTS}

- Autophagy and Pg-p in liver from fish can be used as biomarkers of environmental impact.

- In the liver of fish from an impacted environment, autophagy and MXR are noticed.

- Recovery healthy histology liver is possible in animals kept in a good quality water.

Abstract: Herein we evaluated the histopathological alterations and expression patterns of multixenobiotic resistence (MXR) and autophagic proteins in liver samples of fish chronically exposed to anthropogenic contaminants in a highly polluted river, and then again after they had been transferred to good quality water. Two groups were established: euthanized on the day of capture $(0 \mathrm{~h})$, and maintained for 30 days in a tank (30 d). The fish of $0 \mathrm{~h}$ presented liver with vacuolated and hypertrophic hepatocytes. Also, it was observed strong immunostaining of cathepsin-D, LC3-II and P-gp. Necrosis and apoptosis were also observed throughout the liver. Conversely, the second group (30 d) showed recovery of the liver normal histology and weak immunoreaction of the studied proteins. So, our results indicated that there was a hepatic recovery in the fish kept in good quality water, as showed by the decreased expression of cathepsin-D, LC3-II, and the MXR (P-gp). Therefore, the alterations here observed could be proposed as potential biomarkers to be tested for following the impacts of remediation or mitigation measures to environmental impacts.

Keywords: fish; biomonitoring; ecotoxicology; freshwater.

\section{INTRODUCTION}

Urbanization and industrialization have been the main sources of contamination of water bodies contributing to the degradation of the environment, exposing the aquatics organisms to a complex mixture 
of chemical pollutants [1,2]. Nowadays, it is emerging the notion that even though the individual contaminants are present at concentrations lower than the No Observable Effect Concentration (NOEC), the toxic effects may be detected, and this phenomenon is known as cocktail effects [3].

The tolerance of aquatic species to toxic agents is highly variable. These agents may generate morphological and biochemical changes in aquatic organisms that are indicative of their environmental conditions [4]. In fish, the liver has become an attractive organ for ecotoxicology studies because it has the potential for biotransformation and excretion of xenobiotics, once it has been in direct contact with environmental pollutants absorbed by an animal [5]. Under stress conditions, the liver of fish exhibits morphological and biochemical modifications, which can be used as biomarkers of environmental impact. Several pathways can be involved in these alterations as phase I and II detoxification enzymes, but some still, not were fully assessed and understood.

Currently, autophagy is not only a route of degradation of cellular components, but it has also been associated with environmental impact conditions in various aquatic organisms [6-9]. Unfavorable conditions trigger autophagy via several cellular stressors, including oxidative stress and DNA damage. The microtubule-associated protein light chain 3 II (LC3-II), a structural component during autophagosome formation, and the Cathepsin D, a lysosomal protease have been used as biomarkers of the autophagic process [6]. In this context, autophagy would act as a mechanism of cellular protection against degraded proteins, xenobiotics, damaged organelles, and other structures that may be toxic to cells, restoring cellular homeostasis [10].

Likewise, others processes related to cell protection and responses to multixenobiotics have been investigated with an emphasis on the expression of P-glycoprotein (P-gp) [11-14]. P-gp is a transmembrane carrier glycoprotein present in several aquatic organisms, also known as ABCB1. It is a representative of the superfamily of ATP-binding cassette transporters. P-gp binds to a variety of substrates and facilitates their efflux, preventing the intracellular accumulation of xenobiotics, and thereby causing resistance to them [15].

The armored catfishes of the genus Hypostomus, belonging to the family Loricariidae, are benthic fish with a wide geographic distribution throughout most of the Neotropical regions of Costa Rica to Argentina $[16,17]$. The species Hypostomus francisci is widely distributed in the São Francisco basin and frequently captured on the Itapecerica River, a tributary of the Pará River [18]. Because of its constant association with river sediments, this species is in direct contact with several pollutants that may accumulate in this substrate. This characteristic habitat makes this species a good model for environmental impact studies [2]. The aim of the present study was to investigate the histopathology and expression of P-gp and autophagy pathway proteins in the livers of $\mathrm{H}$. francisci captured in the urban river, which has chronic anthropogenic influences. The study also aimed to evaluate the recovery of the healthy structural organization of their livers after fish were maintained in good quality water.

\section{MATERIAL AND METHODS}

\section{Experimental design}

For the analysis of liver histology and the monitoring of liver recovery after 30 days, 17 adult specimens of $H$. francisci were captured in the urban area of the Itapecerica River in Divinópolis $\left(20^{\circ} 13^{\prime} 09^{\prime \prime} \mathrm{S}\right.$; $44^{\circ} 54^{\prime} 51^{\prime \prime}$ W), Brazil in December 2015, rainy season in Southeastern, Brazil. A voucher specimens were deposited at the Department of Zoology, access number MHN-UFMG 1456. The water quality of this river was historically monitored in series (1997-2012) where it was evidenced by several thermotolerant coliforms (values between $1.0 \mathrm{E}+04$ and $1.0 \mathrm{E}+05 \mathrm{mgL}^{-1}$ ), oxygen dissolved range 6.0 and $8.0 \mathrm{mgL}^{-1}$, phosphorus 0.1 and $0.2 \mathrm{mgL}^{-1}$, and ammonium nitrogen 1.0 and $2.0 \mathrm{mgL}^{-1}$, respectively, being classified as Water Quality Index (WQI) between medium and poor [19]. This generalized pollution can be linked to various organic and industrial effluents present on this river, as a result of poorly planned municipal sewage systems. In addition, the water of the Itapecerica river has already been evidenced as a cause of inflammatory processes, cellular stress, cell death and several morpho-histological alterations in fish gills [2]. The fish were caught in the early morning using different fishing gear (gill nets, casting nets, and trawls), and then quickly transported to the laboratory in plastic tanks supplied with air. In the lab, the fish were divided into two groups. The first group $(\mathrm{N}=9)$ was euthanized with $250 \mathrm{mgL}^{-1}$ benzocaine on the day of capture and dissection was performed. The second group $(\mathrm{N}=7)$ was housed for 30 days in a 150 liters tank with tap water dechlorinated, temperature at $25^{\circ} \mathrm{C}$, constant oxygenation, $\mathrm{pH} 6.8$, and photoperiod $14 \mathrm{~h} / 10 \mathrm{~h}$. The fish were fed daily with commercial feed for 30 days until euthanasia with $250 \mathrm{mgL}^{-1}$ benzocaine. From both groups of fish, length $(\mathrm{L})$ and weight $(\mathrm{W})$ were obtained and used to calculated the 
length-weight relationship (LWR). The parameters $a$ and $b$ were estimate by log- transformed weight and length measurements $\left(\log W=\log a+\log L^{*} b\right)$ [20]. All the procedures were conducted in accordance with the recommendations of the Ethics Committee on Animal Use in Research of Federal University of São João Del Rei, no 49/2010.

\section{Histology and immunohistochemistry}

For the histological analysis, liver fragments from a similar region in all fish were collected and fixed in Bouin liquid for $8 \mathrm{~h}$ at room temperature. Next, the samples were submitted to paraffin inclusion (one block per fish), sectioned with $5 \mu \mathrm{m}$ thickness and the histological sections were stained with hematoxylin and eosin (HE) or periodic acide-Schiff reagent (PAS). For immunohistochemistry, histological sections from eight fish ( $n=4 /$ group) were submitted to the identification the following primary antibodies: Cathepsin $D$ CAT-D (C-20) [21] and Microtubule-associated protein light chain 3 II - LC3-II (N-20) [22] from Santa Cruz Biotechnology and P-glycoprotein - P-gp (C219) [12] from Thermo Fisher Scientific. Briefly, the liver sections were deparaffinized and hydrated, and antigen retrieval was performed with $10 \mathrm{mM}$ sodium citrate buffer for $20 \mathrm{~min}$ at $100{ }^{\circ} \mathrm{C}$. Next, blocking the endogenous peroxidase with $3 \%$ hydrogen peroxide was performed. Blocking of non-specific antigens was done incubating the sections in $2 \%$ BSA buffer solution for $30 \mathrm{~min}$. The sections were then incubated with the primary antibody (anti-CAT-D, 1:200; anti-LC3-II, $1: 200$ or anti-P-gp 1:100) overnight at $4{ }^{\circ} \mathrm{C}$ in a humid chamber. For identification of primary antibodies, the LSAB 2 System HRP Kit from Dako Cytomation (K 0675) containing secondary antibody conjugated to biotin (1:200) and streptavidin conjugated with peroxidase was used. Thus, after washing with PBS the sections were incubated with biotinylated secondary antibody for $45 \mathrm{~min}$ in a dark chamber. Then a solution of streptavidin conjugated to peroxidase was also applied in slides for $45 \mathrm{~min}$ in a dark chamber. The reaction development (primary-secondary antibody-streptavidin-peroxidase) was performed with diaminobenzidine and counterstained with hematoxylin. For negative control, one of the sections do not received primary antibody. The immunoreaction was evaluated by a visual scoring determination in each sample and classified as $0,1+, 2+$, or $3+$ [23]. The evaluation was performed by two independent researchers. In the case of a disagreement, discussion was used to reach a consensus.

For morphometry, liver images were captured in a Motic photomicroscope (BA 310) and morphometric analyzes were performed using the Motic Plus 2.0. Thus, five photomicrographs of the liver were consecutively captured on the $40 \mathrm{X}$ objective ( $\mathrm{N}=3$ animals per group). In each micrograph, the area of 20 hepatocytes were measured ( $\mathrm{N}=300$ hepatocyte per experimental group).

The degree of tissue injury (Degree of Liver Damage - DLD) based on the severity of lesions was used to semiquantify the histological alterations in liver sections stained by HE. The method was adapted from Poleksic and Mitrovic-Ttundzic [24]. The histopathological findings were classified in progressive tissue damage stages: stage I (SI), which do not alter the normal functioning of the tissue (vacuolated cytoplasm, cellular or nuclear hypertrophy, lateral displacement of the nucleus, glycogen present); stage II (SII), which are more severe and impair the normal the functioning of the tissue (hepatocyte apoptosis, fibrosis, degeneration of cytoplasm or nucleus, rectilineation of vessels and parenchyma); and stage III (SIII) alterations, which are very severe (focal necrosis, tumor). A value of DLD was calculated for each fish by the formula: $\mathrm{DLD}=(1 \mathrm{X} \mathrm{SI})+(10 \mathrm{X} \mathrm{SII})+(100 \times \mathrm{SIII})$. DLD values between 0 and 10 indicate normal functioning of the organ; values between 11 and 20 indicate slight damage to the organ; values between 21 and 50 indicate moderate changes in the organ; values between 50 and 100 indicate severe lesions and values above 100 indicate irreversible damage to the organ [24]. Apoptosis was characterized morphologically using the following parameters: nucleus with compacted chromatin at the periphery of the nuclear envelope, cellular retraction and formation of apoptotic bodies. Necrosis was hallmarked by pyknosis and fragmentation nuclear, cellular membrane rupture and karyolysis.

\section{Statistical analysis}

The Shapiro-Wilk test of normality was aplied to verify whether the samples present a normal distribution. Once the data failed the Shapiro-Wilk test of normality, the non-parametric Mann-Whitney test was performed, followed by the Dunn's post hoc test when a significant statistical difference was found. All data were tested using 95\% confidence intervals $(p<0.05)$. All statistical tests were performed using software SigmaPlot (Systat Software Inc.). 


\section{RESULTS}

\section{Animals}

Among the $H$. francisci caught 9 females and 7 males. The biometric data was summarized in the Table 1. The LWR was estimated for $H$. francisci from first group $(0 \mathrm{~h})$ : parameter b was 1.9227, and parameter a was 0.5445 with a determination coefficient $\left(r^{2}\right)$ equal to 0.40 , and in the second group (30 d) the parameter b was 2.0303, and parameter a was $0.7589\left(r^{2}=0.98\right)$. The groups were formed by fish with similar size. In addition, the parameter b showed a tendency to increase after 30 days in good water.

Table 1. Biometric data and parameters of the length-weight relationship $(a$ and $b)$ for $H$. francisci from first group $(\mathrm{N}=$ 9) euthanized on the day of capture (0h) and the second group ( $N=7$ ) euthanized after 30 days in good water (30 d).

\begin{tabular}{lcc}
\hline Biometric Data & $0 \mathrm{~h}(\mathrm{~N}=9)$ & $30 \mathrm{~d}(\mathrm{~N}=7)$ \\
\hline Lenght $(\mathrm{cm})$ & $21.0(\max 25.0-\min 17.0)$ & $22.5(\max 26.0-\min 18.5)$ \\
Weight $(\mathrm{g})$ & $100.0(\max 180.0-\min 50.0)$ & $94.0(\max 132.0-\min 64.0)$ \\
$a$ & 0.5445 & 0.7589 \\
$b$ & 1.9227 & 2.0303 \\
\hline
\end{tabular}

\section{Histology and immunohistochemistry}

In both groups of fish, the liver was surrounded by a thin capsule of connective tissue. The hepatic parenchyma was observed with hepatocyte plates bounded by sinusoids. Each plate was formed by polarized hepatocytes with a sinusoidal and biliary face. The hepatocytes were distributed in cord form and arranged in plates, often two hepatocytes thick. In addition, it was possible to observe a biliary system (Figure 1).

In the specimens of group $1(0 \mathrm{~h})$, the hepatocytes were hypertophics, the nuclei were displaced to the periphery, and abundant cytoplasmic vacuoles were present (Figure 1a and b). Apoptosis in hepatocytes was very frequent (Figure 1b). In addition to apoptosis, necrosis was evident, in several areas of the hepatic parenchyma, being characterized by an area with intense acidophilic properties (Figure 1b). The PAS histochemical in group 1 revealed weak labeling of PAS-positive compounds in the cytoplasm of hepatocytes, indicating few reserves of glycogen (Figure 1c).

In the group 2 specimens (30 days), the liver showed smaller hepatocytes compared with the first group. The vacuolization of the hepatocytes was almost absent. Sinusoid capillaries were less dilated (Figure 1d). Most hepatocytes had central nuclei and eosinophilic cytoplasm (Figure 1d and e). In the hepatic parenchyma, no necrosis areas were registered. The PAS assay showed strong staining in the cytoplasm of hepatocytes, indicating large cytoplasmic glycogen deposits in these cells (Figure 1f). 

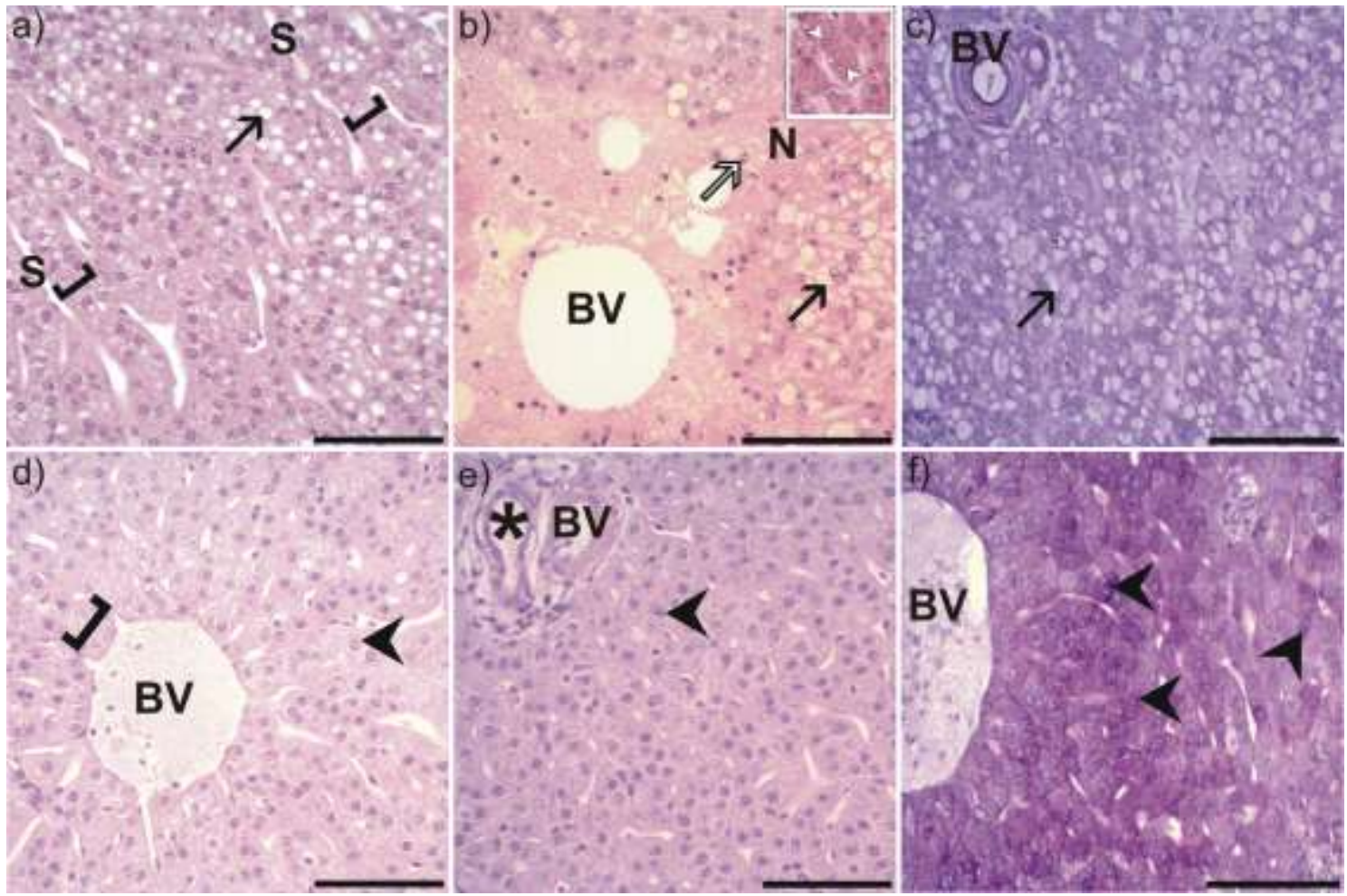

Figure 1. Histological sections from livers of animals Group $10 \mathrm{~h}(\mathrm{a}-\mathrm{c})$ and Group $230 \mathrm{~d}(\mathrm{~d}-\mathrm{f})$. $a-b$ and $d$-e the sections were stained with Hematoxylin and Eosin (HE); $c$ and $f$ the liver was stained with PAS assay. White (nuclei displaced to the periphery) and black (abundant cytoplasmic vacuolization) arrows. N necrosis area; BV blood vessels; S sinusoid capillaries; asterisk bile duct; white (apoptosis) and black (central nuclei) arrowheads; brackets (hepatocyte plates). Note in $\mathrm{c}$ and $\mathrm{f}$ the absent and present of glycogen deposits in cytoplasm from hepatocytes, respectively. Bars $=25 \mu \mathrm{m}$. Insert shows hepatocytes in apoptosis.

Morphological data showed that in group $1(0 \mathrm{~h})$, hepatocytes presented a mean area of $88.30 \pm 21.31$ $\mu \mathrm{m}^{2}$. In contrast, in group 2 (30 days), the hepatocytes were smaller with a mean area of $47.63 \pm 11.58 \mu \mathrm{m}^{2}$ $(\mathrm{p}<0.001)$.

The mean DLD for liver from fish of the first group $(0 \mathrm{~h})$ was 54.11 , indicating severe damage to the organ. The DTC value was lower in the fish from the second group (30 d) (DTC =6.42).

In group $1(0 \mathrm{~h})$, the labeling of P-gp was observed in the plasma membrane of hepatocytes, being more intense in cells close to large blood vessels. The immunoreaction decreased with increasing distance from large vessels (Figure $2 a$ and $\mathrm{c}$ ). However, in group 2 (30 days), the staining was less frequently restricted to hepatocytes near the large blood vessels (Figure $2 b$ ).

In group $1(0 \mathrm{~h})$, cathepsin-D (Figure 2d and f) and LC3-II (Figure $2 \mathrm{~g}$ and i) were labeled in hepatocyte cytoplasm with more intensity in cells with cytoplasmic vacuoles. Contrarily, in group 2 (30 days), the immunostaining these proteins was also cytoplasmic, however with less intensity (Figure $2 \mathrm{e}$ and $\mathrm{h}$ ). 


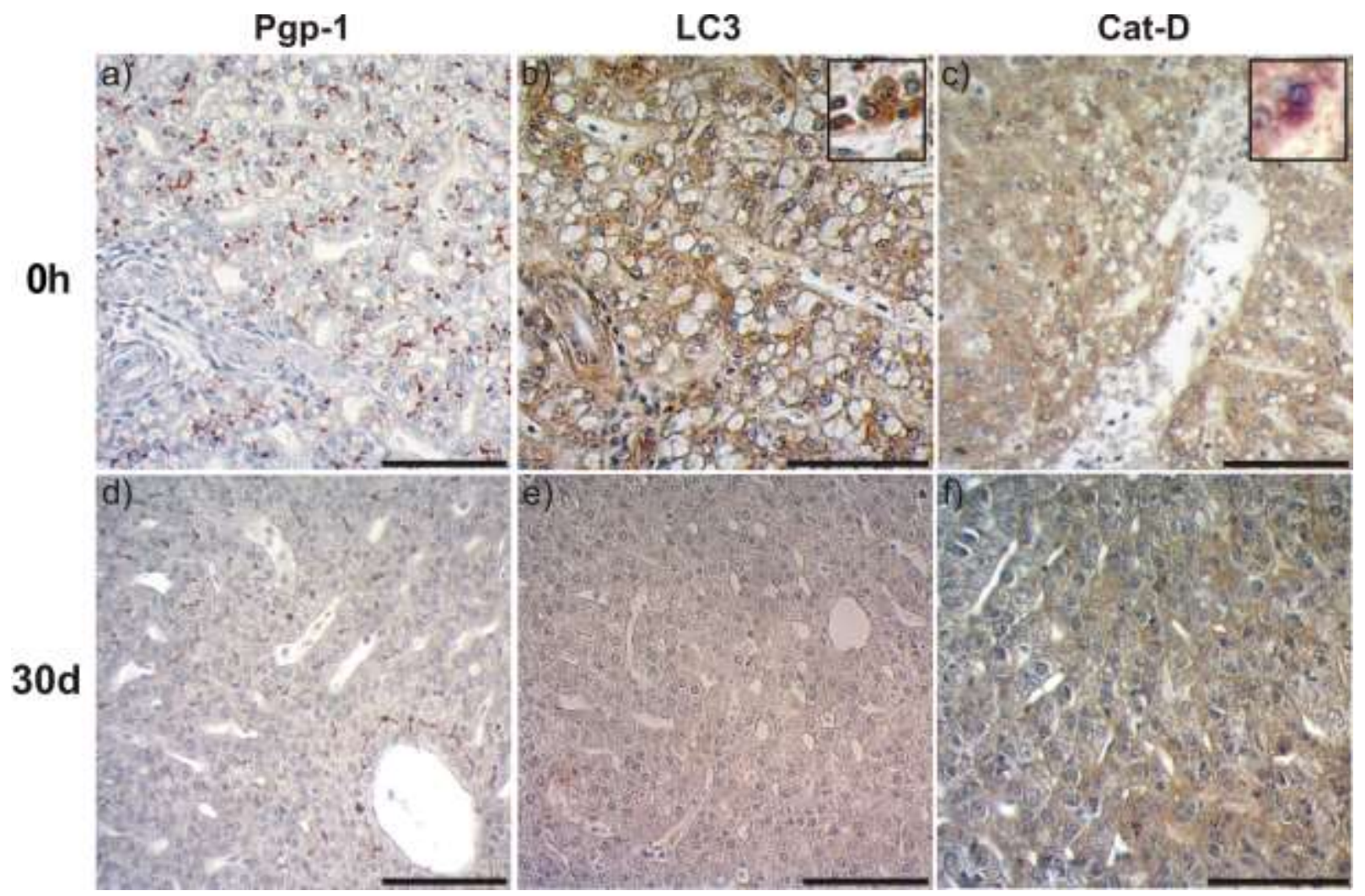

Figure 2. Immunohistochemical staining of Pg-P, LC3-II, and Cathepsin-D in the liver of the $\mathrm{H}$. francisci from $0 \mathrm{~h}$ and 30 d. (a and d) Pg-p reaction in the cytoplasmic membrane, (b and e) LC3-II reaction in cytoplasmic points (see insert in b), (c and f) Cathepsin-D (cat-D) reaction dispersed in the cytoplasm (see insert in c). Positive reactions was detected by intense brown colour. Bars $=25 \mu \mathrm{m}$.

Based on the visual evaluation, all proteins evaluated presented an overexpression (score +3$)$ in the fish recently caught in the Itapecerica River, and no or weak expression (score $0,1+$, or $2+$ ) was observed in fish held in clean water (Figure 3).

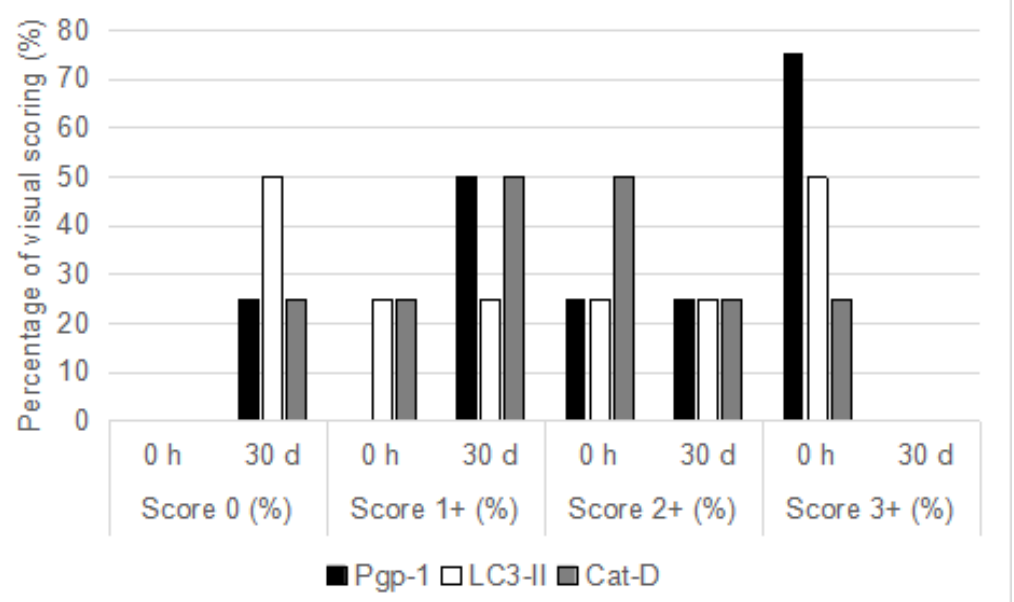

Figure 3. Visual scoring of Pgp-1, LC3-II and Cat-D for $\mathrm{H}$. francisci from first group $(\mathrm{N}=4)$ euthanized on the day of capture $(0 \mathrm{~h})$ and the second group $(\mathrm{N}=4)$ euthanized after 30 days in good water $(30 \mathrm{~d})$ using a four-step scoring system $(0,1+, 2+, 3+)$.

\section{DISCUSSION}

In the present study, we observed the recovery of a healthy structural organization in the livers of fish which had been maintained in favorable environmental conditions. In healthy fish, the hepatic parenchyma is organized into hepatocytes arranged in cords, surrounded by sinusoid capillaries, converging toward a vein. The hepatocytes were regulars, with central nucleus, cytoplasm without vacuolization, and often filled with glycogen. The bile ducts have a simple cubic epithelium, which can become columnar in large ducts. The stroma is composed of thin connective tissue, associated with veins, sinusoids and the biliary system 
[25]. This organization is similar to that found in the livers of animals in the second group, which was maintained for 30 days in good quality water.

The histological changes observed in group 1 may be associated with the urban waste that are released into the Itapecerica River, and could be a response of fish metabolism to unfavorable conditions in the aquatic environment. These environmental stressors may include, but are not limited to, pathogens, parasites, variable temperatures, xenobiotics varied and silting regimes, agglomeration, increased competition, and availability of food and habitat [26,27]. Increased hepatocyte vacuolization [28], necrosis areas [29], nuclear displacement, recruitment of macrophages, and reduced glycogen [30] have previously been used as biomarkers of degenerative processes suggestive of metabolic damage that may be related to exposure to contaminated water. The occurency of apoptosis in several hepatocytes from animals collected from the Itapecerica River suggests a direct consequence of a polluted environment. Similar observations have been reported in several environmental impact studies [21,31].

Hepatocytes are polyhedral epithelial cells of endodermal origin that may undergo hypertrophy and hyperplasia, and these cytological conditions may result from various stimuli, such as chemicals, viral injury, traumatic loss, partial hepatectomy, and other conditions of hepatotoxicity [32]. Here it was observed that hepatocytes were larger in group 1 than those in group 2. This hypertrophy of hepatocytes consists of an increase in the cytoplasmic component and indirectly shows the functional activity of this cell type in response to the presence of xenobiotic agents [33-35]. Hepatocyte hypertrophy has previously been used as an environmental impact biomarker of cellular stress in teleost fish $[33,35]$. The decreased amount of glycogen observed in group 1 is typically found in stressed animals $[36,37]$. It is likely that decreases in glycogen deposits are related to high energy demands for cellular homeostasis recovery under adverse conditions [38]. Moreover, as described by Pereira and collaborators [30], metabolic variations, such as decreased glycogen and cytoplasmic vacuolization may be related to failures in metabolic functions for excretion of substances in the liver and a decrease in glycogenolysis, suggesting a greater energy demand to repair the damage caused by pollutants.

The livers of animals from group 1 had greater amounts of Cathepsin-D and LC3-II than those from group 2; these findings suggest an increase in autophagy processes in order to degrade possible toxic substances or even the organelles themselves if they have been damaged by the absorption of pollutants. The Cathepsin- $D$ is a lysosomal aspartic protease involved in the elimination process of degraded proteins, and when externalized in the cytoplasm can be related to apoptosis [39]. The microtubule-associated protein light chain $3 \mathrm{II} \mathrm{(LC3-II)}$ is a cytosolic protein that undergoes C-terminal cleavage when a proautophagy signal is received by a cell, being converted from form I (LC3-I) to form II (LC3-II). LC3-II undergoes modifications and is localized specifically in the membrane of autophagosomes [7,9,40]. The increased activity of Cathepsin-D has been associated with exposure to pollutants in the livers of both larvae and adults of some teleost species [41]. Autophagy does not only serve as a pathway for protein and organelle degradation, but under certain stress conditions, increased autophagy activity helps cells to counteract stress agents (either external or internal stressors). This action contributes to the ability of cells to adapt to environmental changes [7,9]. On the other hand, once a stressor stimulus has been interrupted caused by decreased cellular volume, the autophagy process is also decreased. This ideia could be applied to explain the improvements seen in the hepatocytes of our group 2 animals.

There is a correlation between the level of pollution identified and the expression of this glycoprotein; therefore, MXR can be considered a generalized biomarker of aquatic contamination [14]. In this study, the results showed that intense labeling in group 1 indicated a high concentration of pollutants in the environment. This result is reinforced by the decreased labeling in group 2, which maintained a basal level of expression. This was also noted by Smital and coauthors [42] who observed that the MXR mechanism can return to its basal level of expression when exposure to contaminants ceases.

In summary, we believe that once a xenobiotic stimulus has been interrupted, the liver of armored catfish showed a return to the healthy morphology. Thus, after a chronic exposition of pollutants, the MXR, herein represented by the P-gp. It was not able to avoid the intense stimulation inside the cell being a trigger of the autophagic pathway (higher expression of Cat-D and LC3-II), that is an attempt to keep cellular viability, and the liver working for the fish survival. Once the stimulus of the generalized pollution was removed, all of the aforementioned pathways stopped to be activated, therefore reducing their expression. Finally, the recovery of healthy morphology of the liver observed at the 30 days might be the result of a process related to cell proliferation and tissue remodeling.

Funding: This research was funded by the Coordenação de Aperfeiçoamento de Pessoal de Nível Superior - Brasil (CAPES) - Finance Code 001. Also this work was supported by Fundação de Amparo à Pesquisa de Minas Gerais 
(FAPEMIG) [grant number APQ-02180-14 and APQ 03548-16]; and the Conselho Nacional de Desenvolvimento Científico e Tecnológico [grant number CNPq-479535/2013-2 and CNPq 405822/2016-2].

Acknowledgments: We would like to thank the Universidade Federal de São João Del Rei (UFSJ/CCO) for equipment and undergrad students scholarship.

Conflicts of Interest: The authors declare no conflict of interest.

\section{REFERENCES}

1. Desbiolles F, Malleret L, Tiliacos C, Wong-Wah-Chung P, Laffont-Schwob I. Occurrence and ecotoxicological assessment of pharmaceuticals: is there a risk for the Mediterranean aquatic environment? Sci. Total Environ. 2018; 639: 1334-48.

2. Sales CF, Santos KPE, Rizzo E, Ribeiro RIMA, Santos HB, Thomé RG. Proliferation, survival and cell death in fish gills remodeling: from injury to recovery. Fish Shellfish Immunol. 2017; 68: 10-8.

3. Beyer J, Petersen K, Song Y, Ruus A, Grung M, Bakke T, Tollefsen KE. Environmental risk assessment of combined effects in aquatic ecotoxicology: a discussion paper. Mar. Environ. Res. 2014;, 96: 81-91.

4. Paulo DV, Fontes FM, Flores-Lopes F. Histopathological alterations observed in the liver of Poecilia vivipara (Cyprinodontiformes: Poeciliidae) as a tool for the environmental quality assessment of the Cachoeira River, BA. Braz. J. Biol. 2012; 72(1): 131-40.

5. Santos Carvalho C, Fernandes MN. Effects of copper toxicity at different $\mathrm{pH}$ and temperatures on the in vitro enzyme activity in blood and liver of fish, Prochilodus lineatus. Mol. Biol. Rep. 2019; 46(5): 4933-421.

6. Moore MN, Allen JI, McVeigh A, Shaw J. Lysosomal and autophagic reactions as predictive indicators of environmental impact in aquatic animals. Autophagy. 2006; 2(3): 217-20.

7. Varga M, Fodor E, Vellai T. Autophagy in zebrafish. Methods. 2015; 75: 172-80.

8. Xing H, Wang Z, Gao X, Chen D, Wang L, Li S, Xu S. Atrazine and chlorpyrifos exposure induces liver autophagic response in common carp. Ecotoxicol. Environ. Saf. 2015; 113: 52-8.

9. Tang BL. Autophagy in response to environmental stresses: New monitoring perspectives. Ecol. Indic. 2016; 60: 453-9.

10. Bolt AM, Klimecki WT. Autophagy in Toxicology: Self-consumption in times of stress and plenty. J. Appl. Toxicol. 2012; 32(7): 465-79.

11. Kurelec B, Smital T, Pivèeviæ B, Eufemia N, Epel D. Multixenobiotic resistance, P-glycoprotein, and chemosensitizers. Ecotoxicology. 2000; 9(5): 307-27.

12. Bard SM, Bello SM, Hahn ME, Stegeman JJ. Expression of P-glycoprotein in killifish (Fundulus heteroclitus) exposed to environmental xenobiotics. Aquat. Toxicol. 2002; 59(3-4): 237-51.

13. Ren T, Fu G-H, Liu T-F, Hu K, Li H-R, Fang W-H, et al. Toxicity and accumulation of zinc pyrithione in the liver and kidneys of Carassius auratus gibelio: association with P-glycoprotein expression. Fish Physiol. Biochem. 2016; 43(1): 1-9.

14. Macêdo AKS, Silva JRP, Santos HB, Thomé RG, Vendel AL, Amado EM. Estuarine fish assemblages present a species- specific difference in the multixenobiotics resistance activity. J. Exp. Zool. A Ecol. Integr. Physiol. 2019; 331(10): 530-9.

15. Kurelec B. Inhibition of multixenobiotic resistance mechanism in aquatic organisms: ecotoxic consequences. Sci. Total Environ. 1995; 171(1-3): 197-204.

16. Zawadzki $\mathrm{CH}$, Weber $\mathrm{C}$, Pavanelli CS. A new dark-saddled species of Hypostomus (Siluriformes: Loricariidae) from the upper rio Paraguay basin. Neotrop. Ichthyol. 2010; 8(4): 719-25.

17. Eschmeyer WN, Fong JD [Internet]. Species by Family/ Subfamily. Eschmeyer's Catalog of Fishes 2014; [cited 2018 Aug 06]. Available from: http://researcharchive.calacademy.org/research/ichthyology/catalog/SpeciesByFamily.asp.

18. Domingos FF, Thomé RG, Ribeiro RIMA, Souza HA, Santos HB. Assessment of fish assemblage in an urban system, Itapecerica River, upper São Francisco River basin, Divinópolis, Minas Gerais, Brazil. Check List. 2013; 9(3): 482-86.

19. IGAM Instituto Mineiro de Gestão das Águas [Internet]. Identificação de municípios com condição crítica para a qualidade de água na bacia do rio Paraopeba 2013; [cited 2018 Oct 12]. Available from: http://www.igam.mg.gov.br/images/stories/ARQUIVO_SANEAMENTO/estudo-saneamento-rio-paraopeba.pdf.

20. Muchlisin ZA, Musman M, Siti Azizah MN. Length- weight relationships and condition factors of two threatened fishes, Rasbora tawarensis and Poropuntius tawarensis, endemic to Lake Laut Tawar, Aceh Province, Indonesia. J. Appl. Ichthyol. 2010;26(6): 949-53.

21. Thomé RG, Domingos FFT, Santos HB, Martinelli PM, Sato Y, Rizzo E, et al. Apoptosis, cell proliferation and vitellogenesis during the folliculogenesis and follicular growth in teleost fish. Tissue Cell. 2012;44(1): 54-62. 
22. Sales CF, Melo RMC, Pinheiro APB, Luz RK, Bazzoli N, Rizzo E. Autophagy and Cathepsin D mediated apoptosis contributing to ovarian follicular atresia in the Nile tilapia. Mol. Reprod. Dev. 2019; 86(11): 1592-602.

23. Wolff AC, Hammond MEH, Hicks DG, Dowsett M, McShane LM, Allison KH, et al. Recommendations for human epidermal growth factor receptor 2 testing in breast cancer: American Society of Clinical Oncology/College of American Pathologists clinical practice guideline update. Arch. Pathol. Lab. Med. 2013; 138(2), 241-56.

24. Poleksić $\mathrm{V}$, Mitrović-Tutundžić $\mathrm{V}$. Fish gills as a monitor of sublethal and chronic effects of pollution. In: Müller R, Lloyd R, editors. Sublethal and chronic effects of pollutants on freshwater fish. Oxford: Fishing News Books; 1994. p. 339-52.

25. Bruslé J, Gonzàlez I, Anadon G. The structure and function of fish liver. In: Munshi JSD, Dutta HM, editors. Fish Morphology. USA: Science Publishers Inc; 1996. p. 77-93.

26. Adams SM, editor. Biological indicators of stress in fish (American Fisheries Symposium). American Fisheries Society, Symposium 8, Bethesda; 1990; Maryland, USA; 1990.

27. Adams SM, editor. Status and use of biological indicators for evaluating the effects of stress on fish. American Fisheries Society, Symposium 8, Bethesda; 1990; Maryland, USA; 1990.

28. Pacheco M, Santos MA. Biotransformation, genotoxic, and histopathological effects of environmental contaminants in European eel (Anguilla anguilla L.). Ecotoxicol. Environ. Saf. 2002; 53(3):331-47.

29. The SJ, Adams SM, Hinton DE. Histopathologic biomarkers in feral freshwater fish populations exposed to different types of contaminant stress. Aquat. Toxicol. 1997; 37(1):51-70.

30. Pereira BF, Alves RMS, Alves AL, Senhorini JA, Rocha RCGA, Scalize PH, et al. Effects of biodegradable detergents in morphological parameters of liver in two neotropical fish species (Prochilodus lineatus and Astyanax altiparanae). Microsc. Res. 2014; 2(2): 39-49.

31. Janz DM, Mcmaster ME, Weber LP, Munkittrick KR, Van Der Kraak G. Recovery of ovary size, follicle cell apoptosis, and HSP70 expression in fish exposed to bleached pulp mill effluent. Can. J. Fish Aquat, Sci. 2001; 58(3): 620-5.

32. Jesus RP, Waitzberg DL, Campos FG. Regeneração hepática: papel dos fatores de crescimento e nutrientes. Rev. Assoc. Med. Bras. 2000; 46(3):242-54.

33. Velmurugan B, Selvanayagam M, Cengiz El, Unlu E. Histopathological changes in the gill and liver tissues of freshwater fish, Cirrhinus mrigala exposed to dichlorvos. Braz. Arch. Biol. Technol. 2009; 52(5):1291-96.

34. Rocha RM, Coelho RP, Montes CS, Santos SSD, Ferreira MAP. Avaliação histopatológica do fígado de Brachyplatystoma rousseauxii (Castelnau, 1855) da Baía do Guajará, Belém, Pará. Ci. Anim. Bras. 2010; 11(1):101-9.

35. Banaee M, Davoodi MH, Zoheiri F. Histopathological changes induced by paraquat on some tissues of gourami fish (Trichogaster trichopterus). Open Vet. J. 2013; 3(1): 36-42.

36. Hinton DE, Laurén DJ. Liver structural alterations accompanying chronic toxicity in fishes: potential biomarkers of exposure. In: McCarthy JF, Shugart LR, editors. Biomarkers of Environmental Contamination. Florida: Boca Raton, Lewis Publishers; 1990. p. 51-65.

37. Wilhelm Filho D, Torres MA, Tribess TB, Pedrosa RC, Soares CHL. Influence of season and pollution on the antioxidant defenses of the cichlid fish Acará (Geophagus brasiliensis). Braz. J. Med. Biol. Res. 2001; 34(6): 71926.

38. Panepucci RA, Panepucci L, Fernandes MN, Sanches JR, Rantin FT. The effect of hypoxia and recuperation on carbohydrate metabolism in Pacu (Piaractus mesotamicus). Braz. J. Biol. 2001; 61(4): 547-54.

39. Silva AG, Lopes CFB, Júnior CGC, Thomé, RG, Santos HB, Reis R, et al. WIN55, 212-2 induces caspaseindependent apoptosis on human glioblastoma cells by regulating HSP70, p53 and Cathepsin D. Toxicol in Vitro. 2019;57:233-43.

40. Tanida I, Ueno T, Kominami E. LC3 and Autophagy. In: Tanida I, Ueno T, Kominami E, editors. Autophagosome and Phagosome. Methods Mol. Biol. 2008; 445:77-88.

41. Kaivarainen EI, Nemova NN, Krupnova MY, Bondareva LA. The effect of toxic factors on intracelular proteinase activity in freshwater fish. Acta Vet. Brno. 1998;67:309-16.

42. Smital T, Sauerborn R, Pivčević B, Krča S, Kurelec B. Interspecies differences in P-glycoprotein mediated activity of multixenobiotic resistance mechanism in several marine and freshwater invertebrates. Comp. Biochem. Physiol. C Toxicol. Pharmacol. 2000;126(2):175-16. 